\title{
Analysis of Capacity Funds Service Distribution-Based on Mayor Regulation (Perwako) in Senapelan Puskesmas, Pekanbaru City, in 2018
}

\author{
Ch. Tuty Ernawati ${ }^{1}$, Aulia Permata Novi ${ }^{2}$, Syafrawati ${ }^{3}$ \\ ${ }^{1}$ Public Health Faculty, Andalas University, Padang, Indonesia \\ *Corresponding author. Email: ernawati.tuti@yahoo.co.id
}

\begin{abstract}
Capitation fund services division in Pekanbaru set in regulation of Mayor (Perwako) No. 26 in 2016, yet the satisfaction of the officer. This study aims to find out about the distribution of capitation services in Senapelan Health Center Pekanbaru City in 2018. This research is qualitative descriptive approach. Retrieving data with in-depth interviews and review documents. The study was conducted in January-June 2019. Determination of informants by purposive sampling. The informants were 8 people. Data analysis was done by triangulation techniques and source. The results showed that the health worker of Senapelan already know about the 6 indices in the division of services. Occupational risk index is not in accordance with the needs and circumstances attendant. The division of services in health centers of Senapelan is not according to Perwako with the index of occupational risk and performance achievements. The division of services capitation funds in health center is not in accordance with the provisions of Perwako. Advice to Pekanbaru City Health Department in order to adjust the index to the needs and circumstances of the officer and to the health center Senapelan to socialize and to set the appropriate calculation points in accordance with Perwako provisions.
\end{abstract}

Keywords: division of service, community health centers

\section{INTRODUCTION}

The capitation fund is the amount of monthly payment paid in advance to FKTP based on the number of participants registered regardless of the type and number of health services provided. The capitation funds are used entirely for payment of health services and support for operational costs.

The allocation of capitation funds for Pekanbaru City is regulated in Pekanbaru Mayor Regulation (Perwako) Number 26 of 2016 concerning the Remuneration of Public Service Centers in the City of Pekanbaru. According to Perwako the allocation of capitation funds for services amounted to $60 \%$ and for operational costs $40 \%$ The amount of incentives for services both direct and indirect services is given based on the results of an index assessment consisting of work tenure index, skills index, science and behavior, work risk index, position index carried, performance achievement index, and attendance index. Based on the results of the initial interview conducted by researchers to the Treasurer of National Health Isurance (JKN) at 5 Pekanbaru City Health Center shows that the distribution of capitation fund services at the Puskesmas still does not meet the satisfaction of Puskesmas staff and there is still a negative response by Puskesmas personnel. These responses include the presence of puskesmas staff who argue that the distribution of services based on the last diploma is inappropriate, the income of medical personnel is too large compared to other personnel, the points in the length of work variable do not significantly affect the services provided, position holders such as Treasurer and technical officer of the activity should not given incentives from services but from operational costs, and the distribution of services is considered to be still not on target because it does not take into account the number of services provided.

Senapelan Puskesmas is one of 12 accredited Puskesmas and is a BLUD Puskesmas in Pekanbaru City. In the 2018 fiscal year, the Senapelan Community Health Center received a capitation fund income of Rp.887,835,900 with 32 employees in the health center. The average income of the Senapelan Health Center services is Rp. 1,513,356 where this income is above the average income of puskesmas services in Pekanbaru is Rp. 1,258,663 and is the 5th highest income of puskesmas in Pekanbaru. Senapelan Puskesmas is a puskesmas that has basic accreditation, which means that the puskesmas commitment to improve its performance is still low. For this reason, researchers are interested in discussing the analysis of the distribution of capitation services at the Senapelan Health Center in Pekanbaru City.

\section{METHOD}

This research is a qualitative research with a descriptive approach to get in-depth information about the distribution 
of capitation fund services based on Perwako in Senapelan Health Center, Pekanbaru City in 2018. This research was conducted from January to June 2019 and the research location was conducted at the Senapelan Health Center. Data collection techniques were carried out, with in-depth interviews and document review. Data analysis used is source triangulation and technique triangulation to find out accurate information.

\section{RESULTS AND DISCUSSION}

Based on the results of the study, information obtained about the length of service index that is puskesmas staff knew about the use of the index of tenure in the distribution of services. This index is considered to be appropriate by puskesmas staff. Calculation of work period index in the Senapelan Health Center is in accordance with the provisions of the Representative. The results showed that the Senapelan Community Health Center staff knew about the use of the science index, skills, behavior in the distribution of services. This index is still considered inappropriate by puskesmas staff. The implementation of this index calculation in the Senapelan Health Center is in accordance with the provisions of the Representative.

In the research results, it was explained that the Senapelan Community Health Center staff knew about the use of work risk index in the distribution of services. This index is still considered inappropriate by puskesmas staff. The calculation of work risk index in the Senapelan Health Center is not in accordance with the provisions of Mayor Regulation (Perwako). The results showed that the Senapelan Puskesmas staff knew about the use of the position index in the distribution of services. This index is still considered inappropriate by puskesmas staff. The calculation of this index in the Senapelan Health Center is in accordance with the provisions of the Representative.

The results showed that the puskesmas staff knew about the use of the performance achievement index in the distribution of services. This index was still considered not appropriate by puskesmas officials. The calculation of this index in the Senapelan Health Center is not in accordance with the provisions of Perwako. The results showed that the Senapelan Community Health Center staff knew about the use of the attendance index in the distribution of services. This index is still considered incompatible by officers. The calculation of this index at the Pusapelan Senapelan is in accordance with the provisions of Perwako.

Based on the results of the study it was found that the health center staff already knew about the mass index work in the distribution of services. This index is considered appropriate by puskesmas staff. This index aims to give awards to officers with a long service period. According to Maslow's theory, appreciation is one of the hierarchy of human needs. This hierarchy of needs is also applied in work motivation. It is therefore expected that the Senapelan Health Center can maintain and continue to use this index as well as possible.

Based on the results of the study, it was found that the puskesmas staff knew about the index of knowledge, skills, and behavior used in the distribution of services. This index is still considered inappropriate by puskesmas staff because it is still calculated by puskesmas staff working outside the field of science and skills. The existence of Puskesmas staff working outside the field of science is caused by the limited human resources at the Puskesmas. This is in accordance with Arifudin's research (2017) which shows that the human resource management system at work placement in UPTD Puskesmas Lembasada is not optimal because there is still a shortage of health workers which results in unsuitable work placements according to scientific disciplines. Therefore, the application of this index should be followed by the fulfillment of human resources at the puskesmas. So that all puskesmas staff work in accordance with their fields of knowledge and skills.

Based on the results of the study, it was found that the health center staff already know about the work risk index used in the distribution of services. This index is still considered inappropriate by puskesmas staff because it does not explain in detail what the risks of working at the puskesmas are and this index point is too high, so it is feared that it will cause imbalances and injustice in the distribution of services. Therefore, this index should explain in detail what work risks might occur at the puskesmas. So that later there will be no inequality and injustice in the calculation of this index.

Based on the results of the study, health center officials already knew about the position index used in the distribution of services. This index is still considered inappropriate by puskesmas staff because double-digit officers get double points in this index. There are officers who hold concurrent positions because of the lack of staff at the puskesmas. This is in accordance with Arifudin's research (2017) which shows that UPTD Puskesmas Lembasada in assigning responsibilities or authority is not good because there are still employees who hold 2-3 programs. Therefore, the application of this index should be followed by the fulfillment of the number of staff at the puskesmas. So that later there will be no puskesmas officers who hold double positions and get double points in this index.

Based on the results of the study, health center officials already knew about the performance achievement index in the distribution of services. This index is still considered not suitable by officers because the work target of officers is too high and not in accordance with the conditions on the ground. Therefore the work target of puskesmas workers should not be determined based on statistical estimates, but also based on actual conditions in the field, such as referring to introspective surveys, puskesmas baseline data, or data from the PIS-PK program.

Based on the results of the study, health center officials already knew about the service period index used in the distribution of services. This index is still considered inappropriate by puskesmas staff because it does not discuss indicators of overtime hours. However, the addition of an overtime indicator is not needed because it will not increase the effectiveness of puskesmas staff at work. As mentioned in Yulmawati's research (2016) which states that the efficiency and effectiveness of nurses' work is caused by 
First Level Health Facilities of the Regional Government, (2016).

setting working hours for nurses so nurses can utilize working hours properly. Therefore, puskesmas staff should make the best use of available working hours, so that later it will increase the effectiveness and efficiency of puskesmas staff at work.

\section{CONCLUSION}

Senapelan Community Health Center officials already know about the six indexes in the distribution of services. However, officials are of the opinion that five of the six indexes do not yet meet their needs and circumstances. The implementation of the index calculation at the Senapelan Health Center is also not fully in accordance with the provisions of Perwako.

\section{REFERENCES}

[1] Regulations of the President of the Republic Indonesia Number 32 of 2014 Concerning the Management and Utilization of the National Health Insurance Capitation Fund at the Local Government's First Level Health Facilities, (2014).

[2] Regulation of the Minister of Health Republic of Indonesia Number 21,2016 concerning Usage National Health Insurance Capitation Fund for Health Services and Operational Cost Support at the
[3] Pekanbaru Mayor Regulation Number 26 Year 2016 Regarding Remuneration of Public Service Centers in the City of Pekanbaru, (2016).

[4] Pekanbaru City Health Service. Pekanbaru City Health Profile 2017 T.A 2018. Pekanbaru: Pekanbaru City Health Service, 2018.

[5] Pekanbaru City Health Service. Pekanbaru City Health Center Accreditation. Pekanbaru: Pekanbaru City Health Service; 2018.

[6] Pekanbaru City Health Service. Payment of Puskesmas Capitation Funds for Fiscal Year 2018. Pekanbaru: Pekanbaru City Health Service; 2018.

[7] Thoha M. Organizational Behavior Basic Concepts and Its Applications. Jakarta: PT Raja Grafindo Persada; 2011

[8] Arifudin, Sudirman, Andri M. Management System Evaluation Human Resources at Work Placement of Officers at UPT Puskesmas Lembasada. Promotive, 2017; 7 (1): 1 - 14.

[9] Yulmawati, Manjas M, Bacthiar H. The Effectiveness of Nurse's Work in Mayjen HA General Hospital Inpatient Installation. Thalib Kerinci Regency Jambi Province. Journal of Public Health. 2012; 6 (2): 67 - 72. 